\title{
IN VITRO MICROPROPAGATION OF Gyrinops walla (GAERTH.) USING LEAF DISC EXPLANTS
}

\author{
A.N. Buddhapriya and W.T.P.S.K. Senarath* \\ Department of Botany, University of Sri Jayewardenepura, Gangodawila, Nugegoda, Sri Lanka
}

\begin{abstract}
Gyrinops walla (Gaertn.) (Thymelaeaceae) is a slender tree which grows in wet zone regions in Sri Lanka. Potentiality of production of resinous natural product, agarwood, which used in perfumery and medicine manufacturing, grant a great demand for this species in worldwide. In vitro micropropagation technique may be a practicable solution to provide healthy planting materials in commercial scale, in order to overcome the problems caused to the natural population due to overexploitation. Thus, using leaf disc explant, possibilities of mass propagation through in vitro techniques was explored in in vitro study. Explants were surface sterilized using $0.2 \%$ carbendazim, $10 \%$ sodium hypochlorite (Clorox) and $70 \%$ ethanol each followed by two successive washings in sterile distilled water. Murashige and Skoog (MS) basal medium supplemented with varied concentrations of different plant growth regulators, 6-benzylaminopurine (BA) and naphthaleneacetic acid (NAA) were tested for induction of calli from leaf discs. Out of different growth regulator combinations, rapid callus growth was observed in MS medium supplemented with $1.0 \mathrm{mg} / \mathrm{L} \mathrm{BA}$ and $3.0 \mathrm{mg} / \mathrm{L}$ NAA within six weeks. Calli obtained were yellowish, compact and callus induction was mainly observed along the midrib. Calli obtain could either be used for mass propagation, through indirect organogenesis or for establishment of plant cell culture to obtain secondary metabolites. From the results obtain, it could be concluded that callus initiation is feasible through leaf disc explant.
\end{abstract}

Keywords: Gyrinops walla, in vitro micropropagation, callus formation, plant growth regulators, leaf disc explant

\section{INTRODUCTION}

Gyrinops is a genus of eight species belongs to family Thymelaeaceae and native to South and South East Asia ${ }^{[12]}$. The species Gyrinops walla (Gaertn.) is native to Sri Lanka and India. The plants grow in scrub jungles, woodlands and small or large forests in wetlands. Also can be found in home gardens as an ornamental plant. Habit of $G$. walla is a medium tall tree that grows up to $15 \mathrm{~m}$ in height with straight, slender trunk and also with a small rounded crown ${ }^{[4]}$. It has dark green thin leaves with small white flowers about one centimetre wide. G. walla is closely related to Aquilaria sp., which may produce a resinous substance called agarwood resin. Agarwood is reputed to be the most expensive wood in the world. There are many names for the resinous, fragrant heartwood produced primarily by trees in the genus Aquilaria and Gyrinops. Most commonly, the resin is known as agarwood, aloeswood, eaglewood, gaharu etc. As a self-defence mechanism, G. walla also produces a resin similar to agarwood which has been well recognized as a primary raw material in perfumery industry worldwide ${ }^{[2]}$. It is also used pharmaceutically as an anti-emetic, sedative and digestive in oriental medical treatments.

Worldwide trading of agarwood is facing a serious shortage of resources because of its disordered collection in forests and the decrease in the tropical rainforest area. G. walla has been listed as a potentially threatened species by the Convention on International Trade in Endangered Species of Wild Fauna and Flora (CITES) due to overexploitation of natural population ${ }^{[1]}$. Efforts have been undertaken to increase the population of G. walla. and variety of methods are used towards this matter. Some recently developed techniques have proven to be more 
effective than previous methods. Developing in vitro micropropagation protocol is one such technique, which could be an applicable solution to implement healthy planting material to produce stocks for commercial scale plantations.

Plant tissue culture is referred to as an in vitro, sterile culture, which is an important tool in basic studies as well as in commercial scale plant propagation ${ }^{[11]}$. For the present study, isolated pieces of a selected leaf disc explants are obtained aseptically from a second fully opened leaves and cultured on a nutrient medium. However, growth induced after transfer of the explants to the nutrient medium supplemented with different plant growth regulators, results in an unorganized mass of calli ${ }^{[7]}$. This mass propagation techniques, then used to generate in vitro multiples shoots or for establishment of plant cell culture to obtain secondary metabolites.

\section{MATERIALS AND METHODS}

A stock of six months to one year old G. walla seedlings were obtained from a forest reserve at Kamburupitiya, which belongs to the low country wet zone in Sri Lanka. All the seedlings were maintained under controlled environment at the Botanical Garden of the Department of Botany, University of Sri Jayewardenepura. Plants were watered regularly and well maintained to protect from insects and fungal attacks. Healthy, young plants were used as the mother stock.

Mother stock was sprayed with $0.1 \%$ Carbendazim® solution a week before collection of explants and then 24 hours prior to collection of explants. Leaf discs from fresh leaves (second and third fully opened) were used as explants in the present study. Explants collected from mother stock was initially washed in water containing $0.01 \% \mathrm{w} / \mathrm{v}$ Teepol and a few drops of Tween 20, then washed under running tap water for 1 hour and finally dipped in a $0.2 \%$ Carbendazim $\AA$ solution for 10 minutes prior to be taken into the laminar flow cabinet.

The explants were surface sterilized in $10 \%$ Clorox for $10 \mathrm{~min}$ and then in $70 \%$ Ethanol for $1 \mathrm{~min}$, each followed by three successive washings in sterile distilled water ${ }^{[3]}$. Leaf discs $\left(5.0 \mathrm{~mm}^{2}\right)$ were prepared centring the midrib and cultured on Murashige and
Skoog (MS) medium ${ }^{[6]}$ supplemented with different concentrations of BA (1.0 - $2.0 \mathrm{mg} / \mathrm{L})$ and NAA (1.0 - $3.0 \mathrm{mg} / \mathrm{L})^{[8]}$. Sucrose $(30.0 \mathrm{~g} / \mathrm{L})$ was added to the medium and the $\mathrm{pH}$ of the medium was adjusted to 5.8. Growth regulator free MS medium was used as the control. Cultures were incubated under a $16 \mathrm{~h}$ light in $25 \pm 1{ }^{\circ} \mathrm{C}$. There were 30 replicates per treatment and Cultures were closely observed for any contaminations. The survival rate of explants, effect of plant growth regulators on callus induction and nature of calli were observed over a period of twelve weeks.

\section{RESULTS AND DISCUSSION}

\section{Percentage Contamination and Survival}

Low rate of contamination (10\%) was observed when leaf discs of $G$. walla were treated with $0.01 \% \mathrm{w} / \mathrm{v}$ Teepol solution with a few drops of Tween 20 followed by $10 \%$ Clorox for $10 \mathrm{~min}$. and $70 \%$ ethanol for 1 min each followed by three successive washings in sterile distilled water despite the fact that explants were collected from the plants grown in the field. Use of optimum concentrations of surface sterilants and exposure period greatly determines the success of the mass propagation technique by means of low contamination percentage and the considerably high leaf disc explant survival. Plants growing in the field are invariably contaminated with microorganisms. These two step, two reagent procedure ${ }^{[5]}$, found to be effective for the surface sterilization of $G$. walla leaf disc explants. It was observed, out of $90 \%$ healthy leaf disc explants, $78 \%$ of them survived yet rest died after browning in a few days after inoculation.

\section{Callus Induction from Leaf Disc Explants}

Callus initiation was observed from leaf disc explants cultured on MS medium supplemented with BA (1.0 $-2.0 \mathrm{mg} / \mathrm{L})$ and NAA $(1.0-3.0 \mathrm{mg} / \mathrm{L})$ over a period of twelve weeks. MS medium supplemented with 1.0 $\mathrm{mg} / \mathrm{L} \mathrm{BA}$ and $3.0 \mathrm{mg} / \mathrm{L}$ NAA was effective in callus induction in $G$. walla. which produced callus within 43 days of incubation (Table 1). Growth regulator free MS basal medium (Control) did not promote the callus induction. 
Table 1: Effect of Plant Growth Regulators on Callus Induction

\begin{tabular}{lll}
\hline $\begin{array}{l}\text { BA } \\
(\mathrm{mg} / \mathrm{L})\end{array}$ & NAA (mg/L) & $\begin{array}{l}\text { Growth* (No. of } \\
\text { Days) }\end{array}$ \\
\hline 1.0 & 1.0 & 55 \\
1.5 & 1.0 & 59 \\
2.0 & 1.0 & 63 \\
1.0 & 2.0 & 57 \\
1.5 & 2.0 & 60 \\
2.0 & 2.0 & 64 \\
1.0 & 3.0 & 43 \\
1.5 & 3.0 & 48 \\
2.0 & 3.0 & 49 \\
\hline
\end{tabular}

* Mean number of days taken to initiate callus induction

Exogenous application of auxin and cytokinin induces callus in various plant species. Generally, an intermediate ratio of auxin and cytokinin promotes callus induction, while a high ratio of auxin to cytokinin or low ratio of auxin to cytokinin, induces root and shoot regeneration, respectively ${ }^{[5]}$. In contrast to that, in the present study, it was observed that high auxin to cytokinin ratios tends to induce calli from the $G$. walla leaf disc explants. NAA - a synthetic auxin and BA - a synthetic cytokinin both induces the cell growth and division. The combination of auxin and cytokinin play an important role on callus growth. However, the activity of auxin and cytokinin varies with the metabolic activities in the plant cells. Due to the presence of high amount of secondary metabolites in leaf disc explants used, their accumulation may affect the optimum activity of plant growth regulators and their ratios. G. walla is a slow growing plant species and with the maturity of the explants, response in in vitro culture may reduce due to the presence of high levels of secondary metabolites in tissues. This might be the reason for slow growth in callus production by explants from mature plants ${ }^{[13]}$.

\section{Nature of Calli}

A number of different expressions of physiological and morphological changes have been reported in callus including loss of exogenous requirement for some growth regulators, changes in biochemical sensitivity and requirements, alterations of growth habit and modifications of cellular components ${ }^{[9]}$.
Variations in the colour and quality of calli changes during its growth were observed (Figure 1).
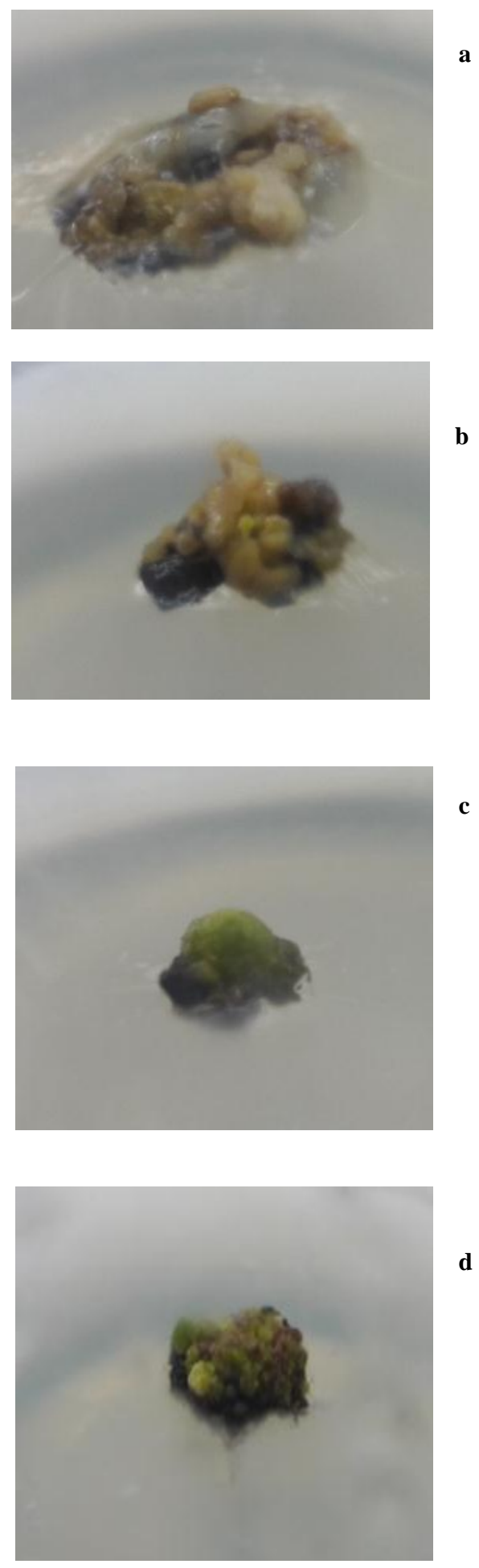

Figure 1. Stages of callus induction and growth of $G$. walla leaf disc explants

At the initial stage of the callus (Figure 1a), cell clusters were white-opaque in colour and fragile in 
nature. During the callus growth with time they become yellow in colour and compact in nature (Figure 1b). This stage is observed as the best to transfer the calli to liquid medium for cell culture to obtain secondary metabolites. When callus become mature on the same medium, then turns to green in colour and become hard due to the production of chlorophyll in the cells (Figure 1c). Greenish callus could be transferred to the multiplication medium for multiple shoot induction. The further accumulation of secondary metabolites, give rise brown colour to the callus (Figure 1d). This does not mean that the decay of the callus, but accumulation of high levels of metabolites. Analysis of the chemical constitutes in the cell clusters at this stage, may provide a qualitative and quantitative measure for the commercially important chemicals.

\section{CONCLUSIONS AND RECOMMENDATIONS}

Surface sterilization using $10 \%$ sodium hypochlorite (Clorox) for $10 \mathrm{~min}$ and $70 \%$ ethanol for $1 \mathrm{~min}$ each followed by two successive washings in sterile distilled water gave the lowest percentage of contamination and highest survival rate for leaf disc explants. Out of different growth regulator combinations, rapid callus growth was observed in MS medium supplemented with $1.0 \mathrm{mg} / \mathrm{L} \mathrm{BA}$ and 3.0 $\mathrm{mg} / \mathrm{L}$ NAA within six weeks. Calli obtained were yellowish compact and callus induction was mainly observed along the midrib. Calli obtain could either be used for mass propagation, through indirect organogenesis or for establishment of plant cell culture to obtain secondary metabolites. From the results obtain, it could be concluded that callus initiation is feasible through leaf disc explant.

\section{ACKNOWLEDGMENT}

This research was granted by the University of Sri Jayewardenepura (USJP), Gangodawila, Nugegoda, Sri Lanka. We are thankful to our colleagues who provided expertise that greatly assisted the research. We have to express our appreciation to the academic staff, Department of Botany, USJP for sharing their pearls of wisdom with us during the course of this research. Principle researcher for this project is Prof. (Mrs) W.T.P.S.K. Senarath, Head/Department of Botany, USJP.

\section{REFERENCES}

Barden, A., Anak, N. A., Mulliken, T. and Song, M. (2000) Heart of the matter: agarwood use and trade and CITES implementation for Aquilaria malaccensis. portals.iucn.org

Brechbill, G. O. (2007) The fragrance industry - profiles. New Jersey: Creative Endeavour Books.

Buddhapriya, A. N. and Senarath, W. T. P. S. K. (2015) In vitro Seed Germination and Callus Induction of Gyrinops walla Gaertn. International Conference on Multidisciplinary Approaches, 192. (ISSN: 2386-1509).

Dassanayake, M. D., Fosberg, F. R. and Trimen, H. (1981) A revised handbook to the flora of Ceylon, New Delhi: Amerind Publishing.

Matthews, R. and Duncan, E. J. (1993) A method to reduce microbial contamination in in vitro culture. Third Caribbean Biotechnology Conference, 160-166.

Murashige, T. and Skoog, F. (1962) A Revised Medium for Rapid Growth and Bio Assays with Tobacco Tissue Cultures. Physiologia Plantarum, 15 (3), 473-497.

Neumann, K. H., Kumar, A. and Imani, J. (2009) Plant Cell and Tissue Culture - A Tool in Biotechnology. Berlin: Springer.

Saikia, M., Shrivastava, K. and Singh, S. S. (2012) An Efficient Protocol for Callus Induction in Aquilaria malaccensis Lam. Using Leaf Explants at Varied Concentrations of Sucrose. International Journal of Plant Research, 2 (6), 188-194.

Skirvin, R. M. (1978) Natural and Induced Variation in Tissue Culture. Euphytica, 27, 241-266.

Skoog F. and Miller C. O. (1957) Chemical regulation of growth and organ formation in plant tissues cultured in vitro. Symposia of the Society for Experimental Biology, $11,118-130$.

Smith, H. R. (2013) Plant Tissue Culture Techniques and Experiments. San Diego: Elsevier Inc.

Subasinghe, S. M. C. U. P., Hettiarachchi, D. S. \& Rathnamalala, E. (2012) Agarwood-type Resin from Gyrinops walla Gaertn: A New Discovery. Journal of Tropical Forestry and Environment, 2 (2), 43-48.

Talukdar, T. (2012) In vitro Regeneration of an Endangered Ornamental Plant Impala Lily (Adenium multiflorum Klotzsch), Indian Journal of Fundamental and Applied Life Sciences, 2 (3), 42-50. 